\title{
RETRACTED: KLASIFIKASI DATA TIME SERIES ARUS LALU LINTAS JANGKA PENDEK MENGGUNAKAN ALGORITMA ADABOOST DENGAN RANDOM FOREST
}

\author{
Ahmad Rofiqul Muslikh ${ }^{(1)}$, Heru Agus Santoso ${ }^{(2)}$, Aris Marjuni ${ }^{(3)}$ \\ ${ }^{1}$ Dosen Universitas Merdeka Malang \\ ${ }^{2,3}$ Dosen Universitas Dian Nuswantoro Semarang \\ ${ }^{1}$ rofickachmad@unmer.ac.id, ${ }^{2}$ heru.agus.santoso@dsn.dinus.ac.id, \\ 3 aris.marjuni@dsn.dinus.ac.id
}

\begin{abstract}
Abstrak:
RETRACTED
\end{abstract}

Following a rigorous, carefully concerns and considered review of the article published in BRILIANT: Jurnal Riset dan Konseptual to article entitled "Klasifikasi Data Time Series Arus Lalu Lintas Jangka Pendek Menggunakan Algoritma Adaboost Dengan Random Forest" Vol 4, No 1, pp. 77-88, February 2019, DOI: http://dx.doi.org/10.28926/briliant.v3i3.272.

This article has been found to be in violation of the BRILIANT: Jurnal Riset dan Konseptual Publication principles and has been retracted.

The editor investigated and found that the article published in Jurnal Teknologi Informasi CyberKU Vol. 14 no 1 Januari 2018, pp. 24-38.

The document and its content has been removed from BRILIANT: Jurnal Riset dan Konseptual, and reasonable effort should be made to remove all references to this article. 